УДК 378.147:811.111:80(043.5)

ЮЛІАНА ЛАВРИШ, кандидат педагогічних наук, доиент кафедри англійської мови технічного спрямування № 2,

Національний технічний університет Украӥни "Київський політехнічний інститут ім. Ігоря Сікорського", Украӥна

ORCID 0000-0001-7713-120X

yulavrysh@gmail.com

\title{
ІНДИВІДУАЛІЗАЦІЯ НАВЧАННЯ ІНОЗЕМНИХ МОВ МАЙБУТНІХ ІНЖЕНЕРІВ: КОНЦЕПТУАЛЬНІ ЗАСАДИ
}

\author{
YULIANA LAVRYSH, PhD in education, assoc.prof. \\ Department of English for Engineering № 2, National \\ technical university of Ukraine "Igor Sikorsky Kyiv \\ polytechnic institute", Ukraine
}

\section{INDIVIDUALIZATION OF FOREIGN LANGUAGE TEACHING OF FUTURE ENGINEERS: CONCEPTUAL PRINCIPLES}

Стаття висвітлює низку концептуальних ідей, що розкривають сутність педагогічних явищ, пов'язаних 3 індивідуалізацією навчання іноземних мов засобами цифрових освітніх технологій. Авторка визначила складові дидактичної структури індивідуалізації навчання іноземних мов, підходи для реалізації навчання автономії; визначила етапи навчання автономії та дидактичні умови для успішної реалізації індивідуалізації навчання іноземних мов. У дослідженні визначено, що саме дидактичний потенціал цифрових освітніх технологій забезпечує успішну реалізацію концепції дослідження.

Ключові слова: індивідуалізація, іноземна мова, цифрові технології, автономне навчання, дидактичні засади.

Summary. The article presents the conceptual principles of individualization in teaching foreign languages to engineering students. The author identified the components of the didactic structure of individualization of foreign language learning and approaches to the implementation of a learner autonomy in education. The stages of learning autonomy and didactic conditions were identified. The article highlights a

(C) Ю. Лавриш number of conceptual ideas that reveal the essence of pedagogical phenomena related to the individualization of foreign language learning by digital educational technologies. The study highlights that the didactic potential of digital educational technologies ensures the successful integration of the research concept.

Key words: individualization, foreign language, digital technologies, autonomous learning, didactic principles.

Мета: представити обгрунтування концептуальних засад процесу індивідуалізації навчання іноземних мов студентів інженерних спеціальностей засобами цифрових технологій.

Постановка проблеми в загальному вигляді. Глобальні інтеграційні процеси сучасного світу - об'єктивна тенденція трансформацій суспільства, але система освіти має створювати умови для адекватної адаптації людини до тих соціокультурних реалій. Зміст освіти відображає рівень розвитку суспільства, його інтереси і потреби, що втілюються в конкретному індивіді, що $\epsilon$ типовим представником даного соціуму. Саме тому сьогодні освітнім пріоритетним напрямом $\epsilon$ індивідуалізація навчання, що перетворюється 3 дидактичного принципу в цілісну систему, яка визначає цілі та завдання кожного аспекту начального процесу. Успішна навчальна діяльність залежить не лише від рівня знань, але й комплексу індивідуальних особливостей, схильностей, інтересів, життєвого досвіду особистості, комунікабельності, уміння встановлювати контакт у різних соціальних групах. Тому сучасні студенти технічних університетів відчувають потребу в навчанні пр о фес ійно - ор іє н тов ан ого спілкування, що дозволяє виявляти себе в ролі повноцінного і компетентного учасника міжкультурної глобальної комунікації, яка в інформаційному соціумі найчастіше відбувається через засоби цифрових технологій.

Аналіз досліджень та публікацій. Проблема індивідуалізації начального процесу через формування навичок автономного навчання вперше запропонована для вивчення Анрі Холеком у праці "Автономія та вивчення іноземних мов" (Holec, 1981). Згідно з визначенням науковця, автономність студентів є базовою формою самоосвіти. Ідеї Холека знайшли відображення у дослідженнях Дама (Dam, 2011), який підкреслює, що для ефективного формування вміння автономного навчання важливою $€$ готовність до співпраці, бажання робити власний вибір та брати на себе відповідальність за це. Згідно 3 дослідженнями Литла (Little, 
2007), успішне оволодіння іноземною мовою залежить від дотримання трьох базових принципів формування навичок автономного навчання: активне залучення студентів у процес навчання, саморефлексія, уміння прийняття рішень та психологічної готовності до автономного способу учіння.

Серед вітчизняних науковців питання психологічно-педагогічних засад організації самостійної роботи студентів у навчанні іноземних мов вивчали I. Задорожна, О. Князян. Так, Задорожна (2012) визначає самостійне індивідуальне навчання студентів як вид пізнавальної діяльності, яка регулюється ним без безпосередньої участі викладача і спрямована на оволодіння відповідними компетентностями. Теоретичні основи використання цифрових освітніх технологій у навчанні іноземних мов представлені в роботах О. Биконі, Н. Авшенюк, М. Жалдака, Л. Морської. Але питання формування автономії навчання іноземних мов студентами інженерних спеціальностей засобами цифрових технологій ще не було детально досліджене в сучасному науковому просторі.

Виклад основного матеріалу дослідження. Система соціальних цінностей демократичного суспільства побудована на принципах поваги та толерантності до кожної особистості, незважаючи на релігійні, національні та культурні відмінності. Усвідомлення їх - це основа для реалізації концепції особистісно орієнтованої педагогіки через індивідуалізацію навчання. Така парадигма розширює поняття індивідуалізації від базового усвідомлення викладачем психофізіологічних особливостей студента до створення індивідуального освітнього простору в результаті індивідуальної самостійної діяльності. Ключовим фактором конструювання ефективної індивідуальної системи саморозвитку є вміння автономного навчання, яке передбачає високий рівень сформованості рефлексії, критичного та креативного мислення, відповідальності та самоорганізації. Ми вбачаємо кореляцію автономного навчання та індивідуалізації через індивідуальну самостійну роботу з урахуванням індивідуальних особливостей сприйняття контенту та засобів взаємодії 3 ним. На наш погляд, автономізація навчального процесу $є$ формою індивідуалізації навчання, оскільки студенти здійснюють самостійне навчання відповідно до індивідуальних потреб, можливостей та власної траєкторії навчання.

Проблема автономного навчання різноаспектно представлена в числених закордонних i вітчизняних наукових працях. Вивчаючи літературні джерела, ми звернули увагу, що термін автономне навчання представлений у двох перспективах: специфічна та загальна. У специфічній перспективі він використовується для опису традиційного самостійного навчання, у якому студент організовуе власну навчальну діяльність за допомогою розробленого плану та варіантів ресурсів, запропонованих викладачем. Загальна автономія передбачає повністю самостійне навчання.

Дидактична структура автономної навчальної діяльності включає: актуалізацію мотивації (визначення мотивів, інтересів та можливостей), самоаналіз освітніх потреб, знань та вмінь, що потребують вдосконалення; планування стратегій діяльності (визначення мети, завдань, вибір засобів і форм навчання), ініціювання діяльності, самоорганізацію та самоконтроль під час імплементації визначених стратегій, самокритичність та саморефлексію результатів діяльності. Ефективність автономної навчально-пізнавальної діяльності студента залежить від рівня сформованості його мотивації, уміння виокремити проблему та засобами критичного мислення окреслювати шляхи іiі вирішення, самоаналізу та саморефлексії. Усе це потребує системи продуманих і цілеспрямованих дій викладача на етапі спільної навчальної роботи під час аудиторних занять або керованої самостійної роботи (Задорожня, 2012). При цьому усвідомлена самооцінка свого вчення стає інтегруючою ознакою навчальної автономії студентів. Ключовим завданням викладача у процесі формування навичок автономного навчання $є$ створення педагогічних умов для ефективного впровадження концепту. Такими педагогічними умовами ми визначили: навчання на основі партнерства між викладачем і студентами; рефлексивність навчального процесу; інтерактивний характер навчання; застосування технологій альтернативного оцінювання та цифрових технологій для моделювання автентичного лінгвокультурного середовища.

3 метою розкриття особливостей автономного навчання іноземних мов засобами цифрових технологій вважаємо доцільним обгрунтувати теоретичні засади інтеграції технологій у навчальний процес. Убачаємо, що ціль трансформації освітнього процесу засобами цифрових технологій максимально повне використання потенційних можливостей цифрових технологій для досягнення педагогічних цілей. У свою чергу, цифрові технології мають бути пристосовані до ефективного вирішення поставлених педагогічних завдань. На нашу думку, сенс інтеграції цифрових технологій в освітній простір у підвищенні соціальної і дидактичної, а не адміністративної якості навчання.

Побудований таким чином цифровий освітній процес сприяє розв'язанню проблеми навчальної мотивації студентів через створення ситуації успіху в навчанні, за рахунок індивідуалізації навчального процесу. Також, мотивуючим фактором виступає якісний і вчасний зворотний зв'язок, який цифрові технології навчання забезпечують кожному студенту безпосередньо у процесі виконання навчальних завдань.

Ми погоджуємось, що цифрове освітнє середовище являє собою комплекс умов і можливостей для навчання, розвитку, соціалізації, виховання людини. Але те, як буде використаний його педагогічний потенціал, залежить від власної суб'єктної активності і навчальної самостійності студента. Під час автономного навчання іноземних мов засобами цифрових технологій реалізується низка підходів, при яких суб'єкти навчального процесу трактуются як:

- активні дослідники цифрових 
інформаційних ресурсів через застосування навичок критичного мислення та вміння оцінювати якість інформації і ресурсів (когнітивний підхід);

- активні учасники взаємодії між об'єктами навчальної діяльності у віртуальному середовищі засобами інтерактивних технологій (інтерактивний підхід);

- дослідники лінгвокультурологічних особливостей іноземних мов (навчально-пізнавальний підхід);

- об'єкти для самодіагностики та самооцінювання власних освітніх потреб і результатів діяльності (рефлексивний підхід);

- активні учасники навчального процесу (студентоцентрований підхід);

- менеджери власної освітньої діяльності відповідно до власних потреб та можливостей (диференційований підхід);

- ініціатори самостійних активних дій на основі здобутого досвіду, знань і навичок (компетентністний підхід);

- конструктори системи власного навчання 3 поєднанням елементів формального та неформального навчання, ураховуючи індивідуальні умови, потреби та досвід (системний підхід).

Ядро концепції компонують ідеї, у яких розкривається сутність цифрових технологій та можливості й переваги їх застосування у процесі навчання автономії майбутніх інженерів. Пропонуємо до розгляду основні ідеї:

- у сучасних реаліях інноваційною $є$ інтенсивність конвергенції цифрових технологій з гуманістичними науками;

- сучасний перехід до навчання засобами цифрових технологій у вищій освіті - це поступове зближення науки, технологій i соціокультурної комунікації, що поглиблює процеси демократизації та гуманізації вищої освіти;

- феномен інтеграції цифрових технологій підштовхує до глобальної переоцінки традиційного підходу до викладання іноземних мов, а також методів навчання i оцінювання (конвергенція традиційних методів 3 використанням цифрових технологій);

- цифрові технології забезпечують індивідуалізацію освітнього процесу, засновану на побу- дові індивідуальних освітніх траєкторій і безперервному персоналізованому моніторингу навчальних досягнень;

- цифрові технологій трансформують ролі та характер взаємин суб'єктів процесу навчання, викладач розглядається як фасилітатор та консультант, а студенти перетворюються на активних учасників процесу навчання, котрі на рівноправних засадах впливають на якість навчання;

- індивідуалізація навчання засобами цифрових технологій створює сприятливе середовище для саморозвитку та самоосвіти особистості 3 метою подальшої самореалізації;

- використання цифрових технологій сприяє диференціації змісту навчання відповідно до потреб студентів.

До ядра концепції також відносимо сукупність науково-педагогічних підходів до розгляду проблеми індивідуалізації іноземних мов засобами цифрових технологій. Основними серед них визначено: гуманістичний, гуманітарний, особистісно діяльнісний, компетентністний, рефлексивний, системний, когнітивний, акмеологічний, аксіологічний, історичний, конвергентний, інтерактивний, інтегральний. У ході дослідження ми виокремили складові автономної навчальної діяльності студентів для вивчення іноземної мови, зокрема її компоненти:

- психологічний - свідоме ставлення до самостійної навчальної діяльності, стійку мотивацію та позитивний підхід до будь-яких результатів навчальної діяльності;

- діагностичний - визначення освітніх потреб і можливостей;

- когнітивно-організаційний постановка завдань, визначення цілей, прийняття рішень, планування власної стратегії навчання, оцінювання релевантності та якості цифрових ресурсів;

- соціокультурний - спілкування 3 партнерами освітнього процесу у віртуальному середовищі, знання Інтернет етикету;

- міжкультурний - спілкування з носіями мови та співпраця із студентами інших країн у процесі оволодіння мовою та виконання проєктів;

- метакогнітивний - самооці- нювання та саморефлексія.

Використання цифрових технологій для формування навичок автономного навчання зумовлено швидкими трансформаціями інформаційного соціуму, необхідністю залучення студентів до стратегій безперервної освіти 3 подальшим формуванням лінгвістичних та інформаційно-комунікаційних компетентностей. Саме дидактичний потенціал цифрових технологій забезпечує успішну реалізацію зазначених цілей. Серед основних дидактичних характеристик ми виокремили такі: свобода у виборі інформаційних ресурсів у глобальній мережі; необмежені можливості для індивідуалізації; множинносуб'єктний характер взаємодій об'єктів навчального процесу; мультимедійність - залучення різних каналів сприйняття інформації (слуховий, зоровий, руховий); нелінійна гіпертекстова характеристика викладу інформації (вільне переміщення по тексту, інфографіка); довідковий, стислий характер інформації, використання перехресних посилань і т. д; гейміфікація для стимулювання невимушеного навчання і підвищення мотивації до навчання через залучення ефекту змагання та емоційної залученості; емоційно-психологічний комфорт для цифрового покоління студентів, субкультурна єдність; адаптація до автентичного мовного середовища; моделювання мовленнєвого середовища.

Висновки та перспективи подальших досліджень. За результатами вивчення нами сформульовані наступні висновки: підвищення мотивації студентів і впевненості у своїх здібностях, усвідомлення власного навчального стилю і володіння навчальними стратегіями, управління власним освітнім процесом і співробітництво з іншими студентами (у тому числі носіями мови), самооцінка навчальних результатів і досягнень сприяє розвитку у них навчальної автономії. Залучення студентів в автономну навчальну діяльність через іншомовне професійне спілкування засобами цифрових технологій дозволяє підвищити показники рівня сформованості умінь професійно-орієнтованого спілку- 
вання у майбутніх фахівців інженерних спеціальностей.

Перспективи подальших досліджень ми вбачаємо у експериментальній апробації дидактичної системи індивідуалізації навчання іноземних мов студентів інженерних спеціальностей.

\section{СПИСОК ЛІТЕРАТУРИ}

Авшенюк, Н. М. (2006). Використання інформаційно-комунікаційних технологій у підготовці вчителів: англійський досвід. Інформаційно-телекомунікаційні технологї в сучасній освіті: досвід, проблеми, перспективи, 1, 508-513.

Жалдак, М. I. (2011) Використа6ння комп'ютера в начальному процесі має бути педагогічно виваженим і доцільним. Комп'ютер в школі та сім'ї, 3, 3-12.

Задорожня, І. П. (2012). Теоретико-методичні засади організації самостійної роботи майбутніх учителів 3 оволодіння англомовною комунікативною компетенцією. (Дисертація доктора педагогічних наук). Київ.

Князян, М. О. (2006). Самостійно-дослідницька діяльність майбутніх учителів іноземних мов: теорія і практика. Ізмаїл : Сміл.

Dam, L. (2011). Developing learner autonomy with school kids:
Principles, practices, results. In D. (Ed.) Fostering Autonomy in Language Learning (pp. 40-52). Gaziantep: Zirve University.

Holec, H. (1981). Autonomy in Foreign Language Learning. Oxford : Pergamon.

Little, D. (2007). Language learner autonomy: some fundamental considerations revisited. Innovation in Language Learning and Teaching,1(1), 1429.

\section{REFERENCES}

Avshenyuk, N. M. (2006). Vy`kory`stannya informacijnokomunikacijny'x texnologij u pidgotovci vchy`teliv: anglijs`ky’j dosvid (Application of educational technologies in teachers' training: England experience). Informacijno-telekomunikacijni texnologiyi $v$ suchasnij osviti: dosvid, problemy', perspekty 'vy', 1 , 508-513.

Zhaldak, M. I. (2011) Vy`kory`sta6nnya komp'yutera $\mathrm{V}$ nachal'nomu procesi maye buty' pedagogichno vy`vazheny`m i docil'ny'm (Application of computer in family should be educationally relevant and thoughtful). Komp'yuter v shkoli ta sim'yi, 3, 3-12.
Zadorozhnya, I. P. (2012). Teorety`ko-metody`chni zasady` organizaciyi samostijnoyi roboty' uchy`teliv z ovolodinnya anglomovnoyu komunikaty`vnoyu kompetenciyeyu (Theoretical and methodological concepts of individual study of future teachers for learning of English communicative competence). (Dy`sertaciya doktora pedagogichny`x nauk). Kyiv.

Knyazyan, M. O. (2006). Samostijno-doslidn y 'cz 'ka diyal'nist' majbutnix uchy'teliv inozemny`x mov: teoriya i prakty`ka (Self-directed research activity of future teachers of foreign languages: theory and practice). Izmayil : Smil.

Dam, L. (2011). Developing learner autonomy with school kids: Principles, practices, results. In D. (Ed.) Fostering Autonomy in Language Learning (pp. 40-52). Gaziantep : Zirve University.

Holec, H. (1981). Autonomy in Foreign Language Learning. Oxford : Pergamon.

Little, D. (2007). Language learner autonomy: some fundamental considerations revisited. Innovation in Language Learning and Teaching, 1(1), 1429.

Стаття надійшла 28.03.2020 p. 